\title{
Greenhouse Gas Emission of Broiler Chicken Production in Malaysia using Life Cycle Assessment Guidelines: A Case Study
}

\author{
Syakira Afiqah Suffian, Atiah Abdullah Sidek, Tohishiko Matsuto, Muataz Hazza Al-Hazza, \\ Hazlina Md Yusof and Abdullah Zawawi Hashim
}

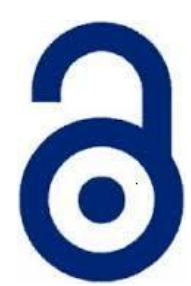

Received: 24 March 2018

Accepted: 18 May 2018

Published: 30 June 2018

Publisher: Deer Hill Publications

(c) 2018 The Author(s)

Creative Commons: CC BY 4.0

\begin{abstract}
The aim of this research was to evaluate the level of greenhouse gas emission from broiler chicken farming industry in Malaysia. In order to achieve that, Life Cycle Assessment method was chosen as a framework to complete the task. A case study was conducted at a broiler chicken farm to gather the data and information related to the broiler chicken production. Cradle-to-gate assessment including distribution stage was conducted based on the ISO14040/1044 guidelines. Inventory data for this case study was gathered in collaboration with one of the selected case study broiler chicken farm company. Greenhouse gas emission that consists of several most affected gases such as carbon dioxide, methane and nitrous oxide was studied. Result shows that the highest carbon dioxide emission came from manure, which accounted for $1,665,342 \mathrm{~kg} \mathrm{CO}$ equivalent per total broilers while the highest methane emission came from feed, which accounted for 126,207.84 $\mathrm{g} \mathrm{CH}_{4}$ equivalent per total broilers. For nitrous oxide emission, the highest values came from bedding which accounted for $20,316.87 \mathrm{~g} \mathrm{~N}_{2} \mathrm{O}$ equivalent per total broilers in the commercial modern broiler chicken farm. In this case study, it can be concluded that manure gives the most prominent effect to the greenhouse gas emission followed by feed and bedding materials.
\end{abstract}

Keywords. Greenhouse gas emission, broiler chicken production, Life cycle assessment.

\section{INTRODUCTION}

Energy and ecological concerns are intricately connected to the supply chains of numerous products. Greenhouse effect (global warming and climate change) as impact category is the harmful ecological consequences to the global climate caused by anthropogenic activity (Walter and Birgit, 2014). Increased community awareness of the dangers postured by global warming has driven towards more prominent concern on top of the impact of anthropogenic carbon emissions to the worldwide climate. Approximately, current level of carbon dioxide $\left(\mathrm{CO}_{2}\right)$ in the atmosphere is approaching $409.97 \mathrm{ppm}$ (Mauna Loa, 2018). From the past of few decades, the environmental concerns has been focusing on companies, government and public. This development was noticeable within regulatory restrictions on industrial contaminant discharges. These strategies concentrates on the treatment and secure disposal of residues and are still in use nowadays when regulatory compliance requirements to be guaranteed. In recent years, there has been substantial awareness in pollution prevention (P2) or cleaner production (CP), in expansion towards pollution prevention control. P2 or CP involves the utilization of methodologies, which attempt to provide essentially clean solutions in order to minimize the necessity of waste management (Raymond et.al 2009).

According to Beauchemin et.al (2010) and Garnet (2010), livestock sector is the most prominent environmental burdens and responsible for $18 \%$ of global greenhouse gasses ( $\mathrm{GHG}$ ) emissions mostly due to the outcome of the

\footnotetext{
S. A. Suffian', A. A. Sidek ${ }^{2}$ 凶, T. Matsuto ${ }^{3}$, M. H. Al-Hazza ${ }^{4}$, H. M. Yusof ${ }^{5}$ and A. Z. Hashim 6

1,2,4 Department of Materials and Manufacturing Engineering

${ }^{5}$ Department of Mechatronics Engineering

International Islamic University Malaysia, PO Box 10, 50728 Kuala Lumpur, Malaysia

${ }^{3}$ Laboratory of Solid Waste Disposal Engineering, Hokkaido University, Japan

${ }^{6}$ Myra Chicken Farm and Services, Kalumpang, Hulu Selangor, Malaysia

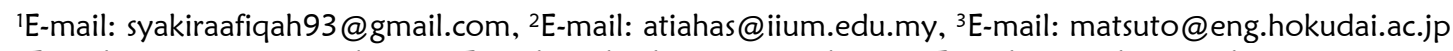
4E-mail: muataz@iium.edu.my, ${ }^{5} \mathrm{E}-\mathrm{mail}$ : myhazlina@iium.edu.my, 6E-mail: awie2k@gmail.com
}

Reference: S. A. Suffian, A. A. Sidek, T. Matsuto, M. H. Al-Hazza, H. M. Yusof and A. Z. Hashim (2018). Greenhouse Gas Emission of Broiler Chicken Production In Malaysia using Life Cycle Assessment Guideline: A case study. International Journal of Engineering Materials and Manufacture, 3(2), 87-97. 
farm activities throughout all the stages of the livestock product lifecycle. Life Cycle Assessment (LCA) is recognized as the most significantly global methods for assessing the environmental impacts of food products (Roy et.al 2009; Jhony et al 2017; Sonko, 2018). The technique assess the environmental aspects and potential impacts of a product's entire lifecycle production chain (ISO 14040:2006). LCA is the favourite method of environmental evaluation because it is the most robust and comprehensive methodology accessible, particularly in environmental research area. Regarding of its record, numerous of authors that conduct environmental assessment choose LCA method as a guideline to study the impact of wide range of food products such as dairy products (Gonzales et.al 2014), broiler chicken in Varamin City (Talayeh et.al 2016), broiler chicken in United Kingdom (Leionen et.al 2012), broiler chicken in France (Seguin et.al 2011) and broiler chicken in Australia (Wiedemann et.al 2012).

Malaysia is one of the major producers of poultry in the Asia Pacific region with export approximately 57.39 million live birds and 13.94 thousand tons of chicken meat to Singapore and some Middle East countries (Orissa, 2017). The consequences of having large production of broiler chicken industry have given the negative impact on the environment. Greenhouse gas emission (GHG) from the broiler production has increased the potential of global warming and resulted in warmer temperature. $\mathrm{GHC}$ emission contains few dangerous gases including methane $\left(\mathrm{CH}_{4}\right)$, carbon dioxide $\left(\mathrm{CO}_{2}\right)$, nitrous oxide $\left(\mathrm{N}_{2} \mathrm{O}\right)$ and ammonia $\left(\mathrm{NH}_{3}\right)$. Therefore, there is a need to investigate the environmental impact especially on greenhouse gas emission (GHG) of the broiler chicken production to produce a sustainable and green production system.

\section{BACKGROUND}

\subsection{Broiler Chicken Production}

Malaysian poultry industry has undergone a transformation over the last decade (Roger, 2010). According to Bernama (2017), Deputy Prime Minister, Datuk Seri Dr Ahmad Zahid Hamidi reported that currently Malaysia has been exported about $7 \%$ of 1.5 million broiler chicken a day. He urged broiler chicken processing companies to increase output up to $28 \%$ for the world market to gain maximum financial profit. Report from Department Veterinary Service (2017) indicated that chicken meat is considered the cheapest source of meat protein and the most popular among consumers in Malaysia because there are no dietary prohibitions restrictions against the consumption of the meat. Figure 1 shows the statistic of broiler chicken production in Malaysia from 2004 to 2017.

Based on Figure 1, the statistic of broiler chicken production has been increasing tremendously every year. This shows a good sign for the development of poultry industry. National broiler production in Malaysia was dominated by broiler contract farming as much as $75 \%$. It is monopolised by several companies and their operations are divided into five categories: grandparent, broiler parent, layer parent, commercial broiler and commercial layer as shown in Table 1 (Syauqi et.al, 2015). Grandparent is a company that specialize in selective breeding meat chickens. Normally they purchase the stock from handful company that based in the US and UK. Broiler is young meat type that is raised normally for 9 to 12 weeks before sending to the market or slaughterhouse while layer is a mature female chicken that kept for egg production and called as laying hens.

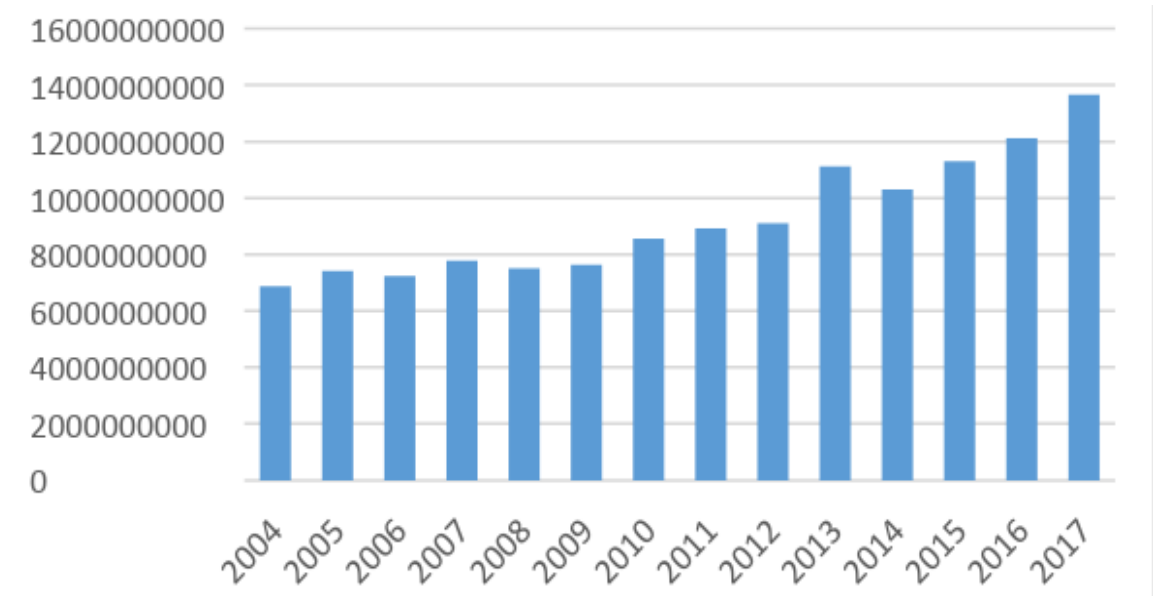

Figure 1: Statistic of broiler chicken production in Malaysia (2004-2017) (Department Veterinary Services, 2017)

Table 1: Statistics of chicken production in Peninsular Malaysia (2010-2013). (Syauqi et.al 2015)

\begin{tabular}{|c|c|c|c|}
\hline Types of Operation & Number of companies & Number of Farms & Population (million) \\
\hline Grand parent & 4 & 4 & 0.90 \\
\hline Broiler parent & 23 & 79 & 11.35 \\
\hline
\end{tabular}




\begin{tabular}{|c|c|c|c|}
\hline Layer parent & 5 & 14 & 0.31 \\
\hline Commercial broiler & Individual/contract & \pm 2600 & 118.52 \\
\hline Commercial layer & Individual/contract & \pm 300 & 47.35 \\
\hline
\end{tabular}

The case study farm falls into commercial broiler category which gives the highest percentage of production among all chicken production. According to Department of Veterinary Services (2018), parent stock (PS) farms stock were supplied 100\% by four grandparent stock farms in 2016. Currently, the parent stock (PS) farms in Peninsular Malaysia has been decreasing from 23 in 2013 to 22 farms in 2017. These farms produce more than 839.08 million broiler day-old-chicks in 2016. Cobbs and Ross are the major chicken breeds used in these farms. There are around 2,403 broiler farms in Peninsular Malaysia producing around 818 million birds in the same year.

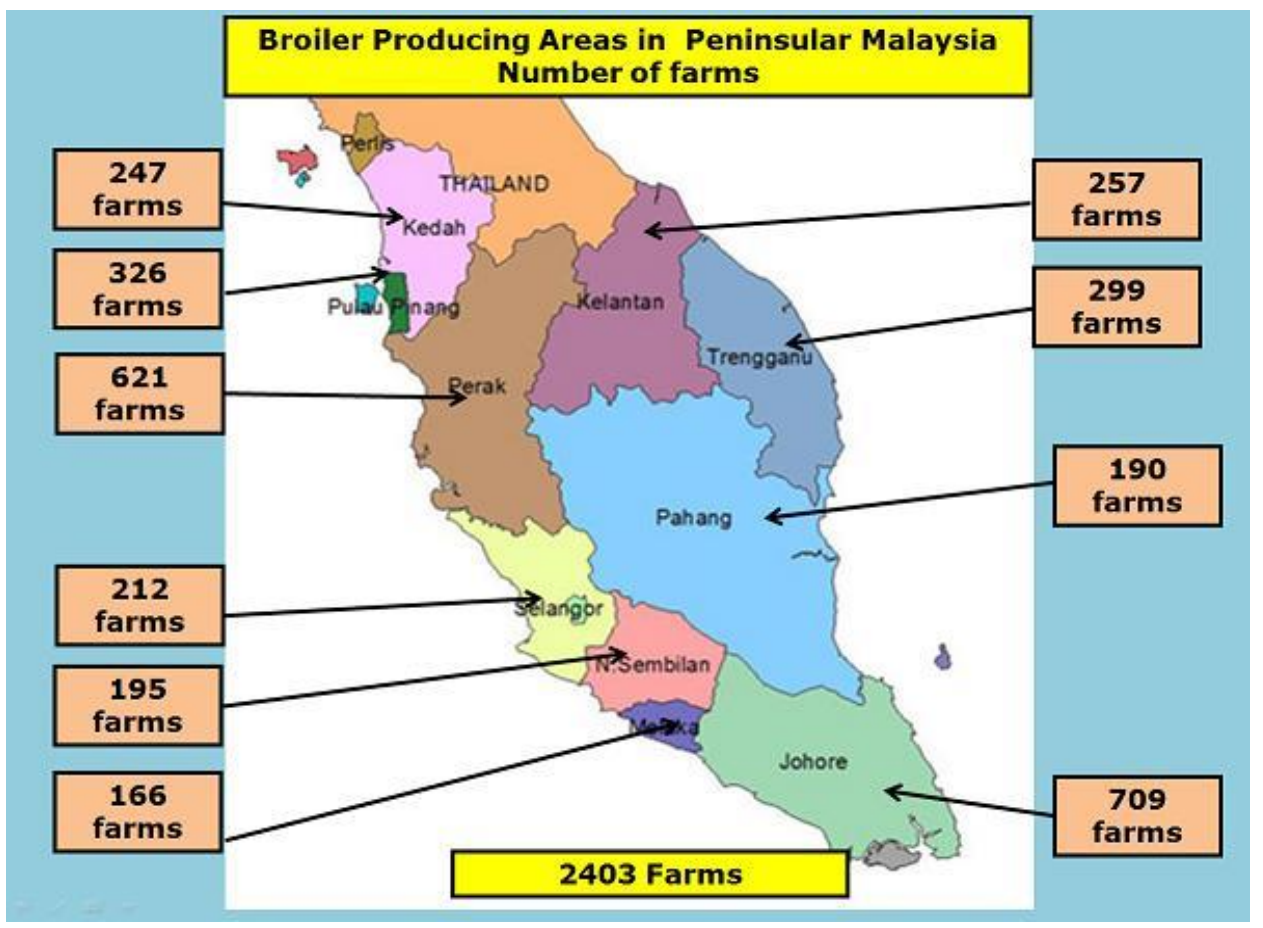

Figure 2: Total commercial broiler farm in Peninsular Malaysia (Department Veterinary Services, 2017)

Figure 2 highlighted the distribution of commercial broiler farms around Peninsular Malaysia with Johor has the most farms and led by Perak where the case study broiler farm is located. Due to severe market competition between the chicken industries, the number of farm companies has been reduced but are getting bigger in production capacity. As seen on Table 1 and Figure 2, number of farms decrease from 2600 in 2013 to 2403 in 2016. However, the production capacity increased from 118 million in 2013 to 818 million in 2016.

\subsection{Life Cycle Assessment}

Life Cycle Assessment standards ISO 14040 and ISO 14044 belong to the ISO 14000 family concerning various aspects of environmental management. The LCA framework according to ISO 14040:2006 in Figure 3 proposed four components of LCA methodology: goal and scope definition; inventory analysis; impact assessment and improvement analysis. Each component in turn has a set of specific constituent activities. 


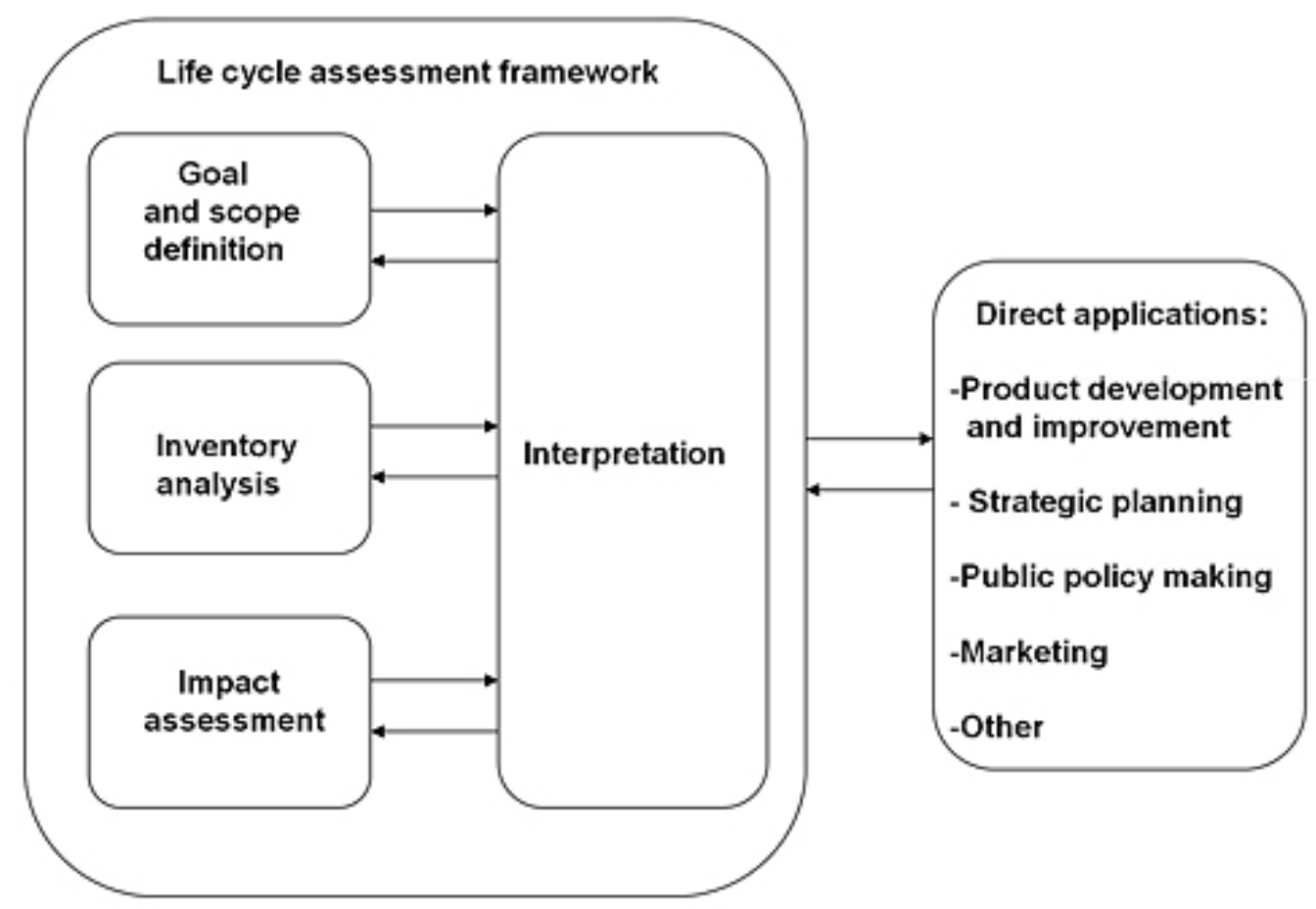

Figure 3: LCA phases according to ISO 14040:2006 (2017)

The LCA framework is introduced with the recommendation of ISO 14040:2006 as shown in Figure 3. Goal and scope definition describes the functional unit chosen, system boundary of research area and the description of the system that need to be studied. This followed by inventory analysis, which defines the input and output of the material involved in the research area including the measurement unit. During the collection of inventory data, there is a need to do material flow analysis so that the input and output material are both balance. The most crucial part in LCA methodology is impact assessment where it assess the product system inventory's result and provide understanding to its environmental significance followed by interpretation.

There has been numerous of authors that conduct environmental assessment choose LCA method as a methodology to study the impact of wide range of food products such as dairy products (Gonzales et.al 2014), broiler chicken in Varamin City (Talayeh et.al 2016), broiler chicken in United Kingdom (Leinonen et.al 2012), broiler chicken in France (Seguin et.al 2011) and broiler chicken in Australia (Wiedemann et.al 2012).

\section{METHODOLOCY}

\subsection{Goal and Scope Definition}

The current analysis and report follows the ISO 14044 guidelines (ISO 14040:2006). The aims of this study were to (1) to evaluate the greenhouse gas emission (GHG) of case study broiler chicken farm and (2) to identify materials/process with major contributions to GHC of broiler chicken production. In order to evaluate the greenhouse gas emission (GHG), life cycle methodology was used and the study covered through a cradle-to-gate perspective from the transportation of one day old broiler chicken into the broiler farm until the transportation of the manure to the plantation farm. The functional unit of $2.5 \mathrm{~kg}$ broiler chicken meat was chosen because it is the amount of chicken meat that contains the recommended daily protein supply for an average family (six people) and it is the average weight of a broiler chicken available for consumption in the market. The calculation was made using the greenhouse gas emission factor obtained from the official website of Environmental Protection Agency (EPA). The study only takes the greenhouse gas emission into account and is calculated according to IPCC 2007 using a 100 year time span. Using IPCC $2007,1 \mathrm{~g} \mathrm{~N} 2 \mathrm{O}$ and $1 \mathrm{~g} \mathrm{CH}$ correspond to $298 \mathrm{~g}$ and $25 \mathrm{~g} \mathrm{CO}_{2}$ respectively.

\subsection{Description of the System and System Boundaries}

An overview of the flow diagram of modern chicken farming supply chain is given in Figure 4. Starting from hatchingegg farm then to hatchery proceed to broiler farm and lastly to slaughterhouse or supplier. 


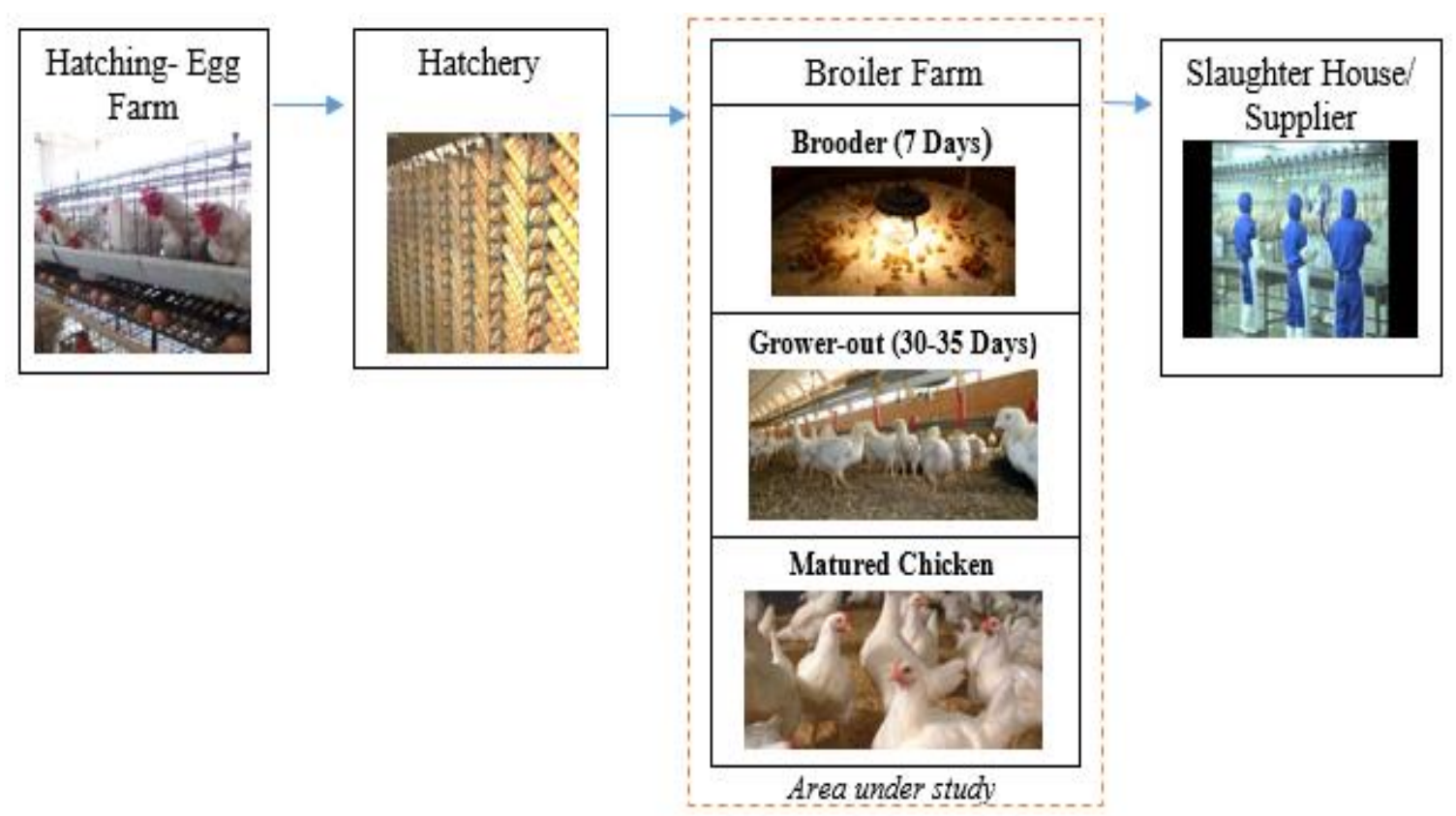

Figure 4: Process flow diagram of modern chicken farming supply chain in Malaysia

Figure 4 shows the process flow diagram of commercial modern chicken farming supply chain in Malaysia. Hatching egg farm is where all layer hens are trained to produce eggs. These eggs will then transferred to hatchery where the eggs are hatched under artificial condition. When day-old chicken were produced, they will then transferred to broiler farm for fattening process and then lastly to slaughterhouse. System boundaries will only limited to the broiler farm where the upper boundary is the transportation of inputs (i.e feeding material, one-day-old broiler chicks, and bedding materials) and the lower boundary is the transportation of outputs (i.e matured broiler chicken and manure). The case study company (Myra Farm \& Services) only received and handled one day-old chicken from hatchery farm and reared them until they are ready enough to be transferred to the next chain- slaughterhouse or chicken supplier. The whole farm consists of four houses where each house accommodates approximately 24,000 to 26,000 broilers. Production systems of the broiler started when the broiler chicks arrived to the farm where they are placed in a containment area with controlled temperature and sufficient amount of feed. Usually, the chicken takes about 35-40 days to achieve specific weight (normally $2.5-3 \mathrm{~kg}$ ) and will then distributed to the nearest market.

\subsection{Material Flow System of the Broiler Chicken Production System}

The broiler chicken farm processed around 100,000 chicks with approximately 40-42 gram weight of each broiler per batch. Each year, they can make a maximum of four batches in which will be approximately 400,000 broilers per year. A material flow diagram was shown in Figure 5 to indicate the amount of materials needed in the system. Numbers shown in the diagram is the average values per batch of the broiler chicken.

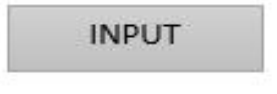

Feed: 477 tones

Bedding: 292.56 tones Electricity: 29665.63 kWh

Water: 869.2 kLiter

Water+detergent (cleaning):

$T=$ transportation

\section{Broiler in:}

$0.004 \mathrm{~kg} / \mathrm{head}$; 106,000 broilers

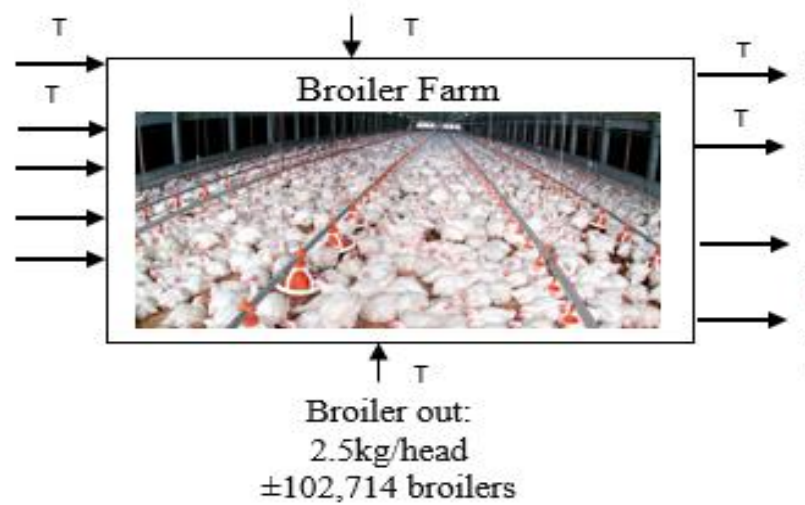

Manure and Bedding: 396.51 tones

Dead birds: $( \pm 3 \%) 3286$ broilers

Waste water: 106.016 kLiter Air Emission: $\mathrm{CO}_{2}$, $\mathrm{CH}_{40} \mathrm{~N}_{2} \mathrm{O}$

Figure 5: Material flow of broiler chicken production system 
The broiler chicks are transported from hatchery to the broiler farm by using lorry that needs a total of 10 trips to complete the transportation process. Before the broilers arrived in the farm, all possible inputs must be prepared for example feed, bedding, and clean environment for the broilers to live in. Normal broilers (weight approximately 2.3 to $2.5 \mathrm{~kg}$ ) need 18 pounds $(8.2 \mathrm{~kg})$ of water and 10.5 pounds $(4.7 \mathrm{~kg})$ of feed to survive throughout their lifecycle in the farm. The volume of bedding used is one of the important elements for the broilers so that it can absorb the moisture from litter and waste water. For the most of the cases, the bedding will be in 7 to $10 \mathrm{~cm}$ deep, which will give about 292.56 tons of shaving wood and bark consumption. Electricity input was calculated by multiplying the usage of fan, light and pump with operation hours. Approximately a total of $29665.63 \mathrm{kWh}$ was used for entire lifecycle of broiler chicken per batch. When the broilers achieved their minimum weight target, which is $2.5 \mathrm{~kg}$, they will be send to slaughterhouse for the next process while the broiler farm will then continue cleaning to prepare for the new batch of broilers. Approximately, 106.016 kilo Litre of water and detergent were used in the cleaning process. The output parameters, manure and bedding volume were calculated based on estimation of number bags of manure being sold to external vendors. These bags can load a maximum of $30 \mathrm{~kg}$ of manure and being sent to various vendor locations depending on order. This broiler farm recorded a mortality rate between 3 to $5 \%$, which is considered acceptably low. Mortality rate above $8 \%$ is considered to be high and cause of alarm. Above $8 \%$ of mortality rate will be considered as high. Mortality causes of broiler chicken is normally due to the changes in weather condition and the quality of feed given. The only wastewater from broiler chicken production in this case study farm was from cleaning activities and is estimated to be around 106.016 kilo Litre.

\subsection{Inventory Analysis}

The broiler chicken farm was assessed and inventory data is collected to quantify the inputs outputs of the production system.. For inventory analysis, data were obtained by taking average measurements and readings to analyse the results. Table 2 shows the main parameters corresponding to the broiler chicken farm under assessment. The selection of broiler breed by the case study farm is based on live production costs and the broiler rapid growth (Cobb, 2017). According to Lobago et.al (2003), Cobb 500 had better overall performance with relatively higher marginal revenue and lower marginal cost compared to Ross in the present small-scale production system in Debre Zeit. For every batch, the farm will receive a total of 106,000 a day-old broiler chicks with fattening period between 35 to 40 days, the feed intake of these broilers during the maturity phase is around $4.7 \mathrm{~kg}$ per broiler and the expected final weight for market is around $2.5 \mathrm{~kg}$. Table 3 presented the inventory data for each process within the boundary production system. The values shown in the Table 3 is the average consumption of the broilers throughout their life cycle in the farm. For example transportation of broilers in from Desaru, Johor which required 5 hours of transportation time. Broiler manure was transported to Cameron Highland, Pahang and feed materials with broiler out were transported to Port Klang, Malaysia's premier port. Information on feed materials was obtained from literature (Weidema, 2013). Amount of water, electricity, animal bedding and cleaning agents were recorded based on average consumption of the broilers per batch.

\section{RESULT AND DISCUSSION}

\subsection{Life Cycle Impact Assessment}

In life cycle assessment guideline, Life Cycle Impact Assessment (LCIA) is identified as one of the important scientific phase. LCIA phase according to ISO 14040 and 14044 is composed of fixed and optional elements. Selection of impact categories, category indicators and characterization models were included in fixed elements for LCIA. There are also parts $\mathrm{f}$ optional element which is assignment of $\mathrm{LCl}$ results as the classification factors and calculation of category indicator results as the characterization factor.

Table 2: Parameters used by the broiler farm

\begin{tabular}{|l|c|}
\hline \multicolumn{1}{|c|}{ Variable } & Closed house broiler \\
\hline Broiler breed type & Cobb500 \\
\hline Average age (until maturity)(days) & $35-40$ days \\
\hline Average feed intake (kg/broiler) & $4.7 \mathrm{~kg}$ \\
\hline Average final weight (kg/broiler) & $2.5 \mathrm{~kg}$ \\
\hline Average mortality rate (\%) & $3 \%$ \\
\hline Number of broilers per batch & 106,000 \\
\hline Type of bedding & Bark, Sawdust \\
\hline Amount of bedding (kg/broiler) & $2.76 \mathrm{~kg}$ \\
\hline
\end{tabular}


Table 3: Inventory data of inputs in the broiler farm.

\begin{tabular}{|l|c|}
\hline \multicolumn{1}{|c|}{ Input } & Unit \\
\hline Transportation (km) & 2395 \\
Broiler in (Desaru-Kalumpang) & 1400 \\
Broiler out (Kalumpang-Port Klang) & 424 \\
Feed (Port Klang-Kalumpang) & 280 \\
Manure (Kalumpang-Cameron Highland) & \\
\hline Feed (kg) & 159,000 \\
Maize & 162,180 \\
Soybean & 127,200 \\
Wheat Branula & 29,680 \\
Fungicides & 869,200 \\
\hline Water (Liter) & $29,665.63$ \\
\hline Electricity (kWh) & 101,760 \\
\hline Broiler bedding (kg) & 190,800 \\
Bark & 1696 \\
Sawdust & 71.02 \\
\hline Gas (MJ) & \\
\hline Cleaning agents (l) & \\
\hline
\end{tabular}

\subsubsection{Selection of Impact Categories, Category Indicators and Characterization Models}

From the life cycle inventory analysis results, the class that representing environmental issues concern or normally being assigned as impact category must be identified according to ISO 14044. In order to represent the impact category, an impact category indicator was defined and falls into classification factor. Characterization factor is a factor that derived from a characterization model, which is applied to convert an assigned inventory analysis result to the common unit of the category indicator.

According to Figure 6, principle of classification and characterization in the phase life cycle impact assessment was mentioned. This research paper will only focusing to one category of GHG factor, which is Global Warming Potential (GWP). In order to investigate the climate change, it is important to use factors published by the IPCC (Intergovernmental Panel on Climate Change) especially owing to varying knowledge and subsequent assessment of indirect impacts. Climate change can be investigate by defining the greenhouse effect and calculate the emissions to determine the GWP.

\begin{tabular}{|c|c|c|c|}
\hline Inventory Results & $\begin{array}{l}\text { Assignment: Inventory } \\
\text { results and impact categories }\end{array}$ & $\begin{array}{l}\text { Characterization model } \\
\text { Characterization }\end{array}$ & Category Indicator \\
\hline $\begin{array}{l}\mathrm{CO}_{2} \\
\mathrm{CH}_{4} \\
\mathrm{~N}_{2} \mathrm{O}\end{array}$ & $\begin{array}{l}\text { Climate change } \\
\text { Emissions with effect on } \\
\text { climate }\end{array}$ & $\begin{array}{l}\text { Quantification of Infrared } \\
\text { radiative forcing relative } \\
\text { to a reference substance }\end{array}$ & $\begin{array}{l}\text { Global warming } \\
\text { potential (GWP) } \\
\text { (kg CO} 2^{-} \\
\text {equivalents) }\end{array}$ \\
\hline
\end{tabular}

Figure 6: Principle of classification and characterization in the phase life cycle impact assessment

\subsection{Global Warming Potential (GWP)}

Global Warming Potential (CWP) is a measure on how much the energy emissions of 1 ton gas will absorb over a given period time. The unit is normally in carbon dioxide equivalent $\left(\mathrm{CO}_{2}\right.$ eq). Effect of high $\mathrm{GHG}$ emission will lead to high Global Warming Potential hence caused the unstable climate change.

\subsubsection{Greenhouse Gas Emission}

Greenhouse gas emission usually emitted from the combustion process. $\mathrm{CO}_{2}$ account the major percentage of emission in greenhouse gas emission. All organizations ought to account for all $\mathrm{CO}_{2}, \mathrm{CH}_{4}$, and $\mathrm{N}_{2} \mathrm{O}$ emissions associated with stationary combustion as advised by EPA (2014). In some cases, the relative emissions contributions of each gas, $\mathrm{CH}_{4}$ and $\mathrm{N}_{2} \mathrm{O}$ are excluded by assuming that they are not material. The method used to calculate $\mathrm{CO}_{2}$ emissions can also be used to calculate emissions of $\mathrm{CH}_{4}$ and $\mathrm{N}_{2} \mathrm{O}$ with tolerable accuracy when applying appropriate $\mathrm{CH}_{4}$ and $\mathrm{N}_{2} \mathrm{O}$ emission factors. 


\subsubsection{Greenhouse Gas Emission Factor}

Emission factor of greenhouse gas emission were obtained from Environmental Protection Agency. These emission factors was proven as one of the methodology to calculate greenhouse gas emission (Nicholas et.al 2017). There are few methods available such as Waste Reduction Model (WARM) and other LCA software. However, this method was the easiest way to estimates the greenhouse gas emission from the activities carried out in the broiler farm. According to Table 4, activities and materials in the broiler farm had their own emission factor based on Environmental Protection Agency guideline. For carbon dioxide and methane, the highest emission factor came from manure which is $4.2 \mathrm{~kg} \mathrm{CO} / \mathrm{kg}$ and $318 \mathrm{~g} \mathrm{CH}_{4} /$ ton while for nitrous oxide emission, bedding which consist of wood and barks gives the highest emission factor which is $63 \mathrm{~g} \mathrm{~N}{ }_{2} \mathrm{O} / \mathrm{ton}$.

Table 4: Greenhouse gas emission factor (Environmental Protection Agency, 2015)

\begin{tabular}{|c|c|c|c|}
\hline $\begin{array}{c}\text { Type of } \\
\text { material/activity }\end{array}$ & $\begin{array}{l}\text { Carbon dioxide emission (kg } \\
\qquad \mathrm{CO}_{2} \text { eq/ton) }\end{array}$ & $\begin{array}{l}\text { Methane emission }\left(\mathrm{g} \mathrm{CH}_{4}\right. \\
\text { eq/ton) }\end{array}$ & $\begin{array}{l}\text { Nitrous oxide } \\
\text { emission ( } \mathrm{g} \mathrm{N}{ }_{2} \mathrm{O} \\
\text { eq/ton) }\end{array}$ \\
\hline Transportation (Diesel) & $2.65 \mathrm{~kg} \mathrm{CO} 2 /$ liter & $0.0333 \mathrm{~g} \mathrm{CH}_{4} /$ miles & $0.0134 \mathrm{~g} \mathrm{~N}_{2} \mathrm{O} / \mathrm{miles}$ \\
\hline Water & $0.8 \mathrm{~kg} \mathrm{CO} / \mathrm{m}^{3}$ & $1.25 \mathrm{~g} \mathrm{CH}_{4} / \mathrm{m}^{3}$ & $0.125 \mathrm{~N}_{2} \mathrm{O} / \mathrm{m}^{3}$ \\
\hline $\begin{array}{l}\text { Feed (Agricultural } \\
\text { products) }\end{array}$ & $3.2 \mathrm{~kg} \mathrm{CO} / \mathrm{kg}$ & $264 \mathrm{~g} \mathrm{CH}_{4} /$ ton & $35 \mathrm{~g} \mathrm{~N}_{2} \mathrm{O} /$ ton \\
\hline Electricity & $1.0 \mathrm{~kg} \mathrm{CO} / \mathrm{kWh}$ & $0.0109 \mathrm{~kg} \mathrm{CH} \mathrm{CH}_{4} \mathrm{MWh}$ & $0.0083 \mathrm{~kg} \mathrm{~N} \mathrm{~N}_{2} \mathrm{O} / \mathrm{MWh}$ \\
\hline Manure & $4.2 \mathrm{~kg} \mathrm{CO} 2 / \mathrm{kg}$ & $318 \mathrm{~g} \mathrm{CH}_{4} /$ ton & $42 \mathrm{~g} \mathrm{~N}_{2} \mathrm{O} /$ ton \\
\hline $\begin{array}{l}\text { Bedding (Wood and } \\
\text { wood residuals) }\end{array}$ & $1.64 \mathrm{~kg} \mathrm{CO} 2 / \mathrm{kg}$ & $126 \mathrm{~g} \mathrm{CH}_{4} /$ ton & $63 \mathrm{~g} \mathrm{~N}_{2} \mathrm{O} /$ ton \\
\hline
\end{tabular}

\subsubsection{Greenhouse Gas Emission Results}

Table 5 illustrates the greenhouse gas emission results after using all the variables given in the table of emission factor and formula. The study was ought to prove the activity or material that contribute the most of greenhouse gas emission to the environment. The results shows that manure gives the total emission of carbon dioxide highest compared to other activity. Carbon dioxide gas was identified to be 1 year $\mathrm{kg} \mathrm{CO} 2$ equivalent per $\mathrm{kg} \mathrm{GHC}$. For the methane emission it was shown that feed contribute to the most of the methane gas which is identified to be 25 year $\mathrm{kg} \mathrm{CO} 2$ equivalent per $\mathrm{kg} \mathrm{GHG}$. Last emission was being studied is nitrous oxide emission and activity that contribute the most is bedding materials. Nitrous oxide was identified to be 298 year $\mathrm{kg} \mathrm{CO}$ equivalent per $\mathrm{kg} \mathrm{GHG}$.

According to the results obtained from Figure 8, activities and materials in the broiler farm which consist of manure, bedding, electricity, feed, water and transportation were examined to investigate their effect on greenhouse gas emission. The result shows that manure gives the highest percentage for Greenhouse Gas Emission (GHG) followed by feed, bedding, transportation activity and electricity. Water give the lowest value to the greenhouse gas emission compared to other materials and activities. Manure was known as organic matter and derived from broilers faeces throughout their lifecycle in the broiler chicken farm. Broiler chicken manure is the source of direct gaseous emissions of ammonia $\left(\mathrm{NH}_{3}\right)$, nitrous oxide $\left(\mathrm{N}_{2} \mathrm{O}\right)$, and to a lesser extent, methane $\left(\mathrm{CH}_{4}\right)$, which occurs during housing, storage, and land spreading (Owen and Silver, 2015). There are several factors that makes manure as the prominent materials that gives the highest greenhouse gas emission which are manure storage and the handling practices. In order to produce a sustainable broiler chicken production system, there is a need to overview the manure management practices so that the percentage of greenhouse gas emission can be reduced and hence reducing the Global Warming Potential.

Table 5: Greenhouse gas emission from broiler chicken production

\begin{tabular}{|l|l|l|l|}
\hline Activity/Material & $\begin{array}{l}\text { Carbon emission } \\
(\mathrm{kg} \mathrm{CO}\end{array}$ & $\begin{array}{l}\text { Methane emission }\left(\mathrm{g} \mathrm{CH}_{4}\right. \\
\text { eq })\end{array}$ & Nitrous oxide emission $\left(\mathrm{g} \mathrm{N} \mathrm{N}_{2} \mathrm{O}\right.$ eq) \\
\hline Transportation & $115,289.12$ & 93.092 & 37.46 \\
\hline Water & 695.36 & 1086.5 & 108.65 \\
\hline Feed & $1,529,792.0$ & $126,207.84$ & $16,732.1$ \\
\hline Electricity & $29,665.63$ & 323.36 & 246.22 \\
\hline Bedding & $479,798.4$ & $40,633.74$ & $20,316.87$ \\
\hline Manure & $1,665,342$ & $126,090.18$ & $16,653.42$ \\
\hline
\end{tabular}




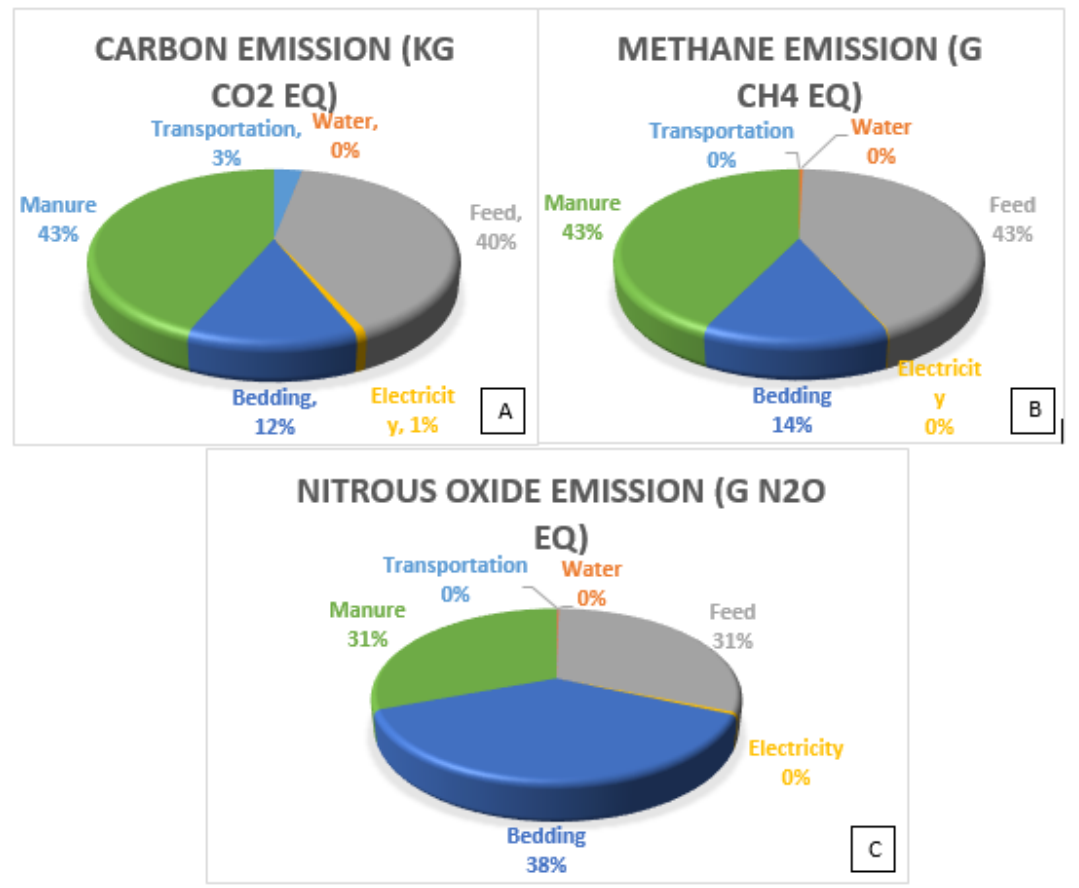

Figure 7: Results of GHG emission; a) carbon emission b) methane emission c) nitrous oxide emission

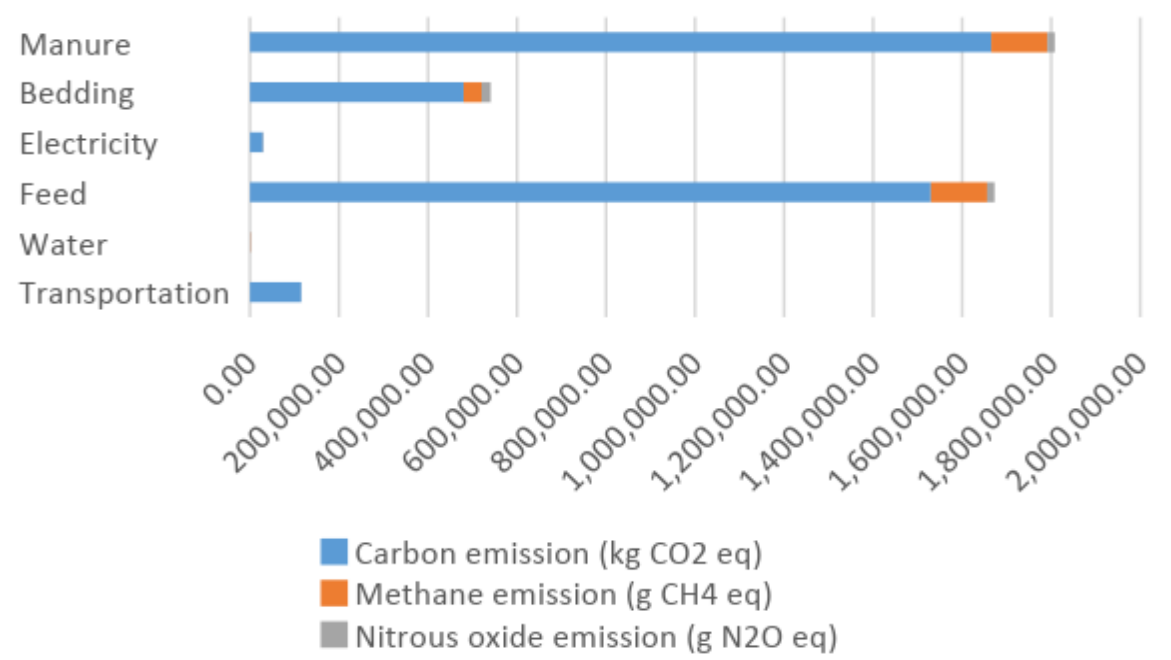

Figure 8: Greenhouse gas emission percentage according to activities in the broiler chicken farm

\section{CONCLUSIONS}

In conclusion, the greenhouse gas emission of the case study broiler production has been examined and identified using Life Cycle Assessment methodology. The presence of high greenhouse gas emission will result on warmer earth temperature and lead to uncontrollable climate change such as ocean acidification, smog pollution and ozone depletion. Malaysia has taken this matter seriously when the government came out with Tenth Malaysia Plan to reduce the greenhouse gas emission by $45 \%$ by 2030 which is the most recent policy of environmental plan (MITI, 2017). Manure is identified as the most prominent factors that contribute to high greenhouse gas emission. Sources of greenhouse gas emission in the farm have been identified to be mainly carbon dioxide $\mathrm{CO}_{2}$, methane $\mathrm{CH}_{4}$ and nitrous oxide $\mathrm{N}_{2} \mathrm{O}$. Much of the greenhouse gases ( $\mathrm{GHG}$ ) generated from this research is primarily from the process of handling and storing faeces of the broilers. This research showed: 
1. The highest carbon dioxide emission came from manure, which accounted for $1,665,342 \mathrm{~kg} \mathrm{CO} 2$ equivalent per total of broilers in the commercial modern broiler chicken farm.

2. The highest methane emission also came from feed and manure, which accounted for $126,207.84 \mathrm{~g} \mathrm{CH}_{4}$ equivalent per total broilers in the commercial modern broiler chicken farm.

3. The highest nitrous oxide emission came from bedding materials, which accounted for $20,316.87 \mathrm{~g} \mathrm{~N} \mathrm{~N}_{2} \mathrm{O}$ equivalent per total broilers in the commercial modern broiler chicken farm.

4. In 2009 , Malaysia has announced voluntary commitment to reduce carbon emission by $40 \%$ of its greenhouse gas emission by 2020 hence exposing the research gap on how we actually can reduce it from poultry side.

5. Therefore, an examination on how much the total emission of greenhouse gas emission was studied before finding ways to reduce it.

\section{ACKNOWLEDGEMENT}

This research was funded by Ministry of Higher Education (MOHE) through Fundamental Research Grant Scheme (FRCS 16-019-0518), to which the authors are grateful. Special thanks also goes to all workers from case study broiler farm in helping the author getting more information on broiler chicken production.

\section{REFERENCES}

1. Beauchemin, K. A., Janzen, H. H., Little, SM., McAllister, TA., McGinn, SM. (2010). Life Cycle assessment of greenhouse gas emissions from beef production in western Canada: A case study. Agric. System. 103, 371-379.

2. Cobb, V. (2017). Generation of process: Cobb500. http://www.cobb-vantress.com/products/cobb-500. (Accessed on December 2017).

3. Daily $\mathrm{CO}_{2}$ records. (2018, March). Retrieved from: https://www.co2.earth/daily-co2.

4. Deborah, NH., Thomas, DE. (2009). A life cycle assessment of Portland cement manufacturing: comparing the traditional process with alternative technologies. Journal of Cleaner Production 668-675.

5. De Varies, M., De Boer, IJM. (2010). Comparing environmental impacts for livestock products: A review of life cycle assessment. Livestock Science 128, 1-11.

6. Department of Veterinary Service (DVS), 2017. http:// www.dvs.gov.my (Accessed on 18 January 2018).

7. Deputy Prime Minister Malaysia aims to export $30 \%$ of broiler chickens by 2030 . Available at: http://www.thepoultrysite.com/poultrynews/39514/dpm-malaysia-aims-to-export-30-of- broiler-chickens-by2030/

8. Environmental protection agency. (2015). Emission factors of greenhouse gas inventories. https://www.epa.gov/sites/production/files/2015-07/documents/emission-factors_2014.pdf (accessed 23 November 2017).

9. Garnett T. (2009). Livestock-related greenhouse gas emission: impacts and option for policy makers. Environmental Science Policy 12,491-503.

10. Garnett T. (2011). Where are the best opportunities for reducing greenhouse gas emissions in the food systems (including food chain)? Food policy 36,523-532.

11. Gonzales, GS., Gomez, FZ., Dias, AC., Feijoo, G., Moreira, MT., Arroja, L. (2014). Life cycle assessment of broiler chicken production; A portuguese case study. Journal Cleaner Production 74, 125-134. http://dx.doi.org/10.1016/j.jclepro.2014.03.067.

12. ISO 14040:2006, ISO 14040:2006 2017-Environmental management; Life cycle assessment: Principle and Framework. Iso.org. http://www.iso.org/standard/37456.html. (Accessed 13 June 2017)

13. Jhony, JL., Alberto, A. A., Luis, FM., Catherine, AP., Jorge, RP., Jose, OR. (2018). Environmental impact assessment of chicken meat production via an integrated methodology based on LCA, simulation and genetic algorithms. Journal of Cleaner Production, 174;477-491.

14. Klopffer, W. (1997). Life Cycle Assessment-from the beginning to the current state. Environmental Science Pollution Research., 4, 223-228.

15. Leiononen, I., Williams, AG., Wiseman, J., Guy, J., Kyriazakis, J. (2012). Predicting the environmental impacts of chicken systems in the United Kingdom through a life cycle assessment: Broiler production systems. Poultry Science 91:8-25.

16. Lobago., Melese., Mideksa., Bizunesh., Tibbo., Markos. (2003). Comparative performance of two broiler hybrids (Cobb-500 and Ross) under small-scale production system in Debre Zeit, central Ethiopia. Bulletin of animal health and production in Africa. Bulletin des santé et production animales en Afrique. 51. 83-93.

17. Martins, C. (2014). Poultry business: Feasibility study on Poultry Farming in Nigeria., 2014. https://martinslibrary.blogspot.com/2014/11/poultry-business-feasibility-study-on.html (accessed on 28 November 2017)

18. Ministry of International Trade and Industry (MITI). (2017) Malaysia and the United Nations Framework Convention on Climate Change (UNFCC)-The Paris Agreement. Trade and Industry Related Emerging Issues Division. 
19. Nikolas, Hill., Rebekah, Bramwell., Billy, Harris. (2017). 2017 Government GHG Conversion Factors For Company Reporting. Department for Business Energy \& Industrial Strategy (BEIS).

20. Owen, J. J., \& Silver, W. L. (2015). Greenhouse gas emissions from dairy manure management: a review of fieldbased studies. Global change biology, 21(2), 550-565.

21. Poultry sector in South East Asia: lowa Economic Development Authority, (2017). Orissa International Pte.Ltd.2017.

22. Raymond, RT., Alvin, BC., Michael, RIP., Joel, QT. (2009). Life Cycle Design, Planning and Assessment. IGI Global.

23. Reckmann, K., Traulsen, I., Krieter, J. (2012). Environmental impact assessment-methodology with special emphasis on European pork production. J. Environmental Manag. 107, 102-109.

24. Roger, A. (2010). Another positive year for Malaysia's broiler producer. https://www.wattagnet.com/articles/7240-another-positive-year-for-malaysia-s-broiler-producers (Accessed on 2 December 2017).

25. Roy, P., Nci, D., Orikasa, T., Xu, Q., Okadome, H., Nakamura, N., Shiina, T. (2009). A review of life cycle assessment (LCA) on some food product. J. Food Eng. 90:1-10.

26. Sabine, CL., Feely, RA., Gruber, N., Key, RM., Lee, K., Bulliester, JL. (2004). The oceanic sink for anthropogenic $\mathrm{CO}_{2}$. Science 305:367-71.

27. Seguin, F., Hayo, VDW., Isabelle, B., Eve, P. (2011). Environmental analysis of organic broiler production in France and improvement options.

28. Sonko, SP. (2018). Express assessment of environmental impact of agriculture technologies on the soils of Cherkasy Oblast. Ukrainian Journal of Ecology, 8(1); 451-459.

29. Syauqi, M., Zaffrie, M., Hasnul, HI. (2015). Broiler Industry in Malaysia. Economic Science Headquarters MARDI. 1-5.

30. Talayeh, K., Ali, R., Asadollah, A., M, Sharifi. (2016). Environmental impact assessment of chicken meat production using life cycle assessment. Journal Information Processing in Agriculture 3(4):262-271. http://doi.org/10.106/j.inpa.2016.10.002.

31. Walter, K., Birgit, G. (2014). Life cycle assessment (LCA): A guide to best practice. Wiley-Vch.

32. Weidema, BP., Bauer, C., Hischier, R., Mutel, C., Nemecek, T., Reinhard, J., Vadenho, CO., Wernet, G. (2013). Overview and Methodology. Data Quality Guideline For The Ecoinvent Database Version 3. Ecoinvent Report 1(v3). The Ecoinvent Centre, St. Gallen.

33. Wiedemann, S., McGahan, E., Poad, G. (2012). Using life cycle assessment to quantify the environmental impact of chicken meat production. 